\title{
NEW AND INNOVATIVE SOLUTIONS FOR IMPROVING TOURISM EDUCATION AND RAISING SATISFACTION OF STUDENTS IN ARMENIA
}

The main aim of the research is to reveal gaps and problems of the tourism education, to evaluate the level of students' satisfaction with educational process results and technologies in Armenia. The methodical instruments of the study include statistic methods and SWOT-analysis. The research is formed by the following structural and logical scheme: the first part observes the investigation of the educational process organizational mechanism and analyzes educational programs in tourism industry at higher educational institutions and at the vocational educational institutions in Armenia, the second part demonstrates the results of the inquiry among students, graduates and workers of the tourism industry regarding their expectations and attitude to the study, the third part systematizes complaints and students' proposals, which can be considered in future with purpose to improve the educational process. The respondents' selection consists of 100 persons, $30 \%$ of which are graduates, $70 \%$ - students. $47 \%$ of participants mention that they do not work and $53 \%$ of respondents work. $55 \%$ of participants have an employment experience in the tourism industry, $45 \%$ - not in the tourism industry. During the study most participants (47\%) evaluate the obtained knowledge as mostly theoretical with some little practical orientation, $27 \%$ - as theoretical, $19 \%$ point out that theoretical and practical parts are the same, but only $7 \%$ of respondents suppose that the obtained knowledge and skills are those, which are adapted to the practice. In order to evaluate the satisfaction level of the educational process results, the system of criteria is proposed in the article. They define the respondents' subjective acceptance regarding the efficiency of the obtained theoretical knowledge and practical skills to be competitive at the national and international markets, to find work, to claim for high salary etc. The cross table method defines the satisfaction level of the educational process by every factor, which determines it. The Pearson criterion calculation enables to confirm the statistic value of the obtained results. Next stage of the study is the respondents' inquiry regarding the significance level of the relevant disciplines for the professional identity in the tourism industry. The results of this study forms a base to correct the structure of the curriculums according to the labour market demands in the tourism industry. The carried out inquiry shows that tourism education in Armenia has many other problems: scientific investigations in this industry are mostly theoretical, a few number of trainings and individual lessons, inefficient organization of the practical training and internships, lack of lecturers-experts, absence of an ability to master modern specific software goods, which are used in the tourism industry etc. The study empirically confirms and theoretically proves that new methods of teaching in the tourism industry are obligatory requirements to satisfy the labour market needs, and students are primary consumers of the educational service, who aware their rights as consumers' rights and put higher demands to the education quality. The research shows that students highly evaluate and prefer the interactive methods of study. The results of the study may be useful for educational institutions (in the context of educational programs improvement), for representatives of tourism business (for the sake of cooperation development with educational institutions while specialists' training) and for students.

Key words: tourism, education, speciality, skills, satisfaction, Armenia.

Introduction. Tourism education has a significant role in the promotion of tourism industry, as skilled labor force with professional background is the main asset as a human capital. Nowadays, labor market needs professional specialists, so one of the most important issues of tourism development is ensuring correspondence between tourism education and labour market. It is necessary to ensure practical education in universities in order the students to learn practical, useful subjects, gain all the crucial competences for being competitive in labour market. 
The purpose of the research was to find out the main problems that are now available in tourism education organization system and evaluate the satisfaction of students with their education in Armenia.

The organization of education is crucial, as the students must have all the necessary subjects, theoretical background, practical skills. Nowadays, being flexible, having strategic mind, analytical skills, leadership, organizing, planning, decision making, time management skills, as well as having professional background, are required by the labour market. Thus, the education system must provide all the decisive competences for students. The education system must meet the needs and requirements of tourism industry. Besides, tourism development requires highly skilled specialists in that sphere, who will carry out research, process and implement policy.

Thus, the above-mentioned issues are of high importance, that is why the rationale and the logic of the research were to investigate the gaps in tourism education organization and evaluate the opinions and satisfaction of students and graduates. Students may feel satisfaction or dissatisfaction during studying, and sometimes they may evaluate it only after graduating, when they compare their knowledge with the requirements of labor market. So, this research aims at exploring the above-mentioned issues and make some suggestions to improve tourism education in Armenia.

Tourism has a significant impact on world economy. International tourist arrivals reached 1,235 million in 2016. The direct contribution of Travel \& Tourism to GDP was USD 2,306.0bn (3.1\% of total GDP) in 2016 in the world, while the total contribution of Travel \& Tourism to GDP was USD 7,613.3bn (10.2\% of GDP) in 2016. In 2016 Travel \& Tourism directly supported 108,741,000 jobs (3.6\% of total employment), and the total contribution of Travel \& Tourism to employment, including jobs indirectly supported by industry, was $9.6 \%$ of total employment (292,220,000 jobs) (Travel \& Tourism Economic Impact, World 2017).

Literature review. The definition adopted by the United Nations in 1954 states that "Tourism is an active rest influencing on the health recovery and physical development of a human body, and is related to traveling outside of the permanent place of residence" (Bogolyubov, 2005).

Tourism education began as a development of technical/vocational schools in Europe, which organized training in core competencies such as hospitality, hotel management and related business skills (Morgan, 2004). Interest and demand from the public and private sectors impelled rapid growth of tourism studies and the establishment of departments of travel and tourism at higher education institutions in addition to technical schools (Butler, 1999).

In order to meet the needs of tourism industry, Business Enterprises for Sustainable Travel think tank developed a set of curriculum modules to teach students the relevance among principles of sustainable tourism and specific management techniques, and how to apply such knowledge. These modules teach students "to identify, understand and address how current and future sustainability issues might impact their operation and their stakeholders" (Jurowski, 2002).

Tourism is a person-to-person activity, which quality depends on the education and motivation of its employees (Sola, 2002). Education is the key to develop human capital, therefore, tourism education is crucial for improving employees' abilities and promoting the industry. Tourism education not only raises personnel quality, but also promotes sustainable tourism development.

Tourism education has to balance three imperatives: the need to promote individual development, the need to advance knowledge, and the need to be practical and relevant to industry (Riley et al., 2002). On the one hand, tourism industry development depends on the quality of labor force, and on the other hand, tourism education has a crucial role in meeting the needs of knowledge required by the industry to develop human capital.

The recent studies show that the academic performance of students have been improved by active learning technique (learning by doing) (Green \& Sammons, 2014). Another advance may be considered the organization of online learning, which enables to expand the distance and geography of learning. 
Tourism researchers state the benefits of online learning compared to face to face learning (Annaraud \& Singh, 2017). Besides, the organization of internships is very crucial for students as future specialists. Internships are considered to be one of the most effective models of experiential learning in tourism and hospitality education (Yiu \& Law, 2012). Together with active learning, online learning and experiential learning, the use of virtual field trips (Patiar, Ma, Kensbock \& Cox, 2017) in educational process is developing. Thus, in the world of global changes tourism education and industry also changes, and the new techniques in tourism education are imperative requirements of labor market needs.

According to Atay and Yildrim (2010) the education is like a service produced by the universities. Thus, the students, paying a tuition fee or not, may be considered to be its customers. Sander, Stevenson, King, and Coates (2000) mention that the current climate in higher education suggests that students could be seen as primary customers, who are becoming increasingly aware of their customer rights.

Students' expectations of teaching and learning depend on the institutional culture and the mode of study (Stevenson \& Sander, 1998). Sander et al. (2000) found that students were taught by formal lectures, but they actually preferred more interactive lectures and group-based activities. Furthermore, in terms of whom students rated as good teachers, those with good teaching skills and approachable attitudes were preferred over teachers who were knowledgeable and well organized.

Methodology. For the analysis we have investigated the educational programs in higher and vocational educational institutions in Armenia. Besides, a survey was conducted among the students, graduates and employees of tourism sphere to find out their opinion on the problems of organizing tourism education and their offers. The main results were analyzed using cross-tabulations with chi square, phi, Cramer's $V$ and contingency coefficient analyses. The main results were resumed in SWOT matrix.

Discussion and findings. In 20171.494 .779 tourists visited Armenia, which is $18.7 \%$ more than last year (Social-economic situation in the RA in January-December, 2017). In Armenia in 2016 Travel \& Tourism directly supported 38,500 jobs (3.3\% of total employment) and the total contribution of Travel \& Tourism to employment was $12.5 \%$ of total employment $(143,500$ jobs) (Travel \& Tourism Economic Impact, Armenia 2017).

According to the Travel \& Tourism Competitiveness Report 2017, Armenia was the 45th with human resources and labor market index, with the primary education enrollment rate (net \%) subindex was the $59^{\text {th }}$, with the secondary education enrollment rate (gross \%) subindex was the $79^{\text {th }}$, with the extent of staff training subindex was the $107^{\text {th }}$, with the degree of customer orientation was the $52^{\text {nd }}$, with the hiring and firing practices subindex was the $19^{\text {th }}$, with the ease of finding skilled employees subindex was the $123^{\text {rd }}$ (The Travel\&Tourism Competitiveness Report, 2017).

Analysis of tourism educational programs in higher and vocational educational institutions in Armenia. In Armenia tourism specialists are being prepared in the following educational institutions (bachelor's degree) (Decision of the Government No 434-N of April 20, 2017):

1. Yerevan State University, "Service" specialization;

2. Yerevan State University ljevan branch, "Tourism" specialization;

3. Armenian State University of Economics, "Tourism", "Service" specializations;

4. Armenian National University of Architecture and Construction, "Tourism" specialization;

5. Yerevan State Linguistic University after V. Bryusov, "Service" specialization;

6. M. Nalbandyan State University of Shirak, "Service" specialization;

7. H. Tumanyan State University of Vanadzor, "Service" specialization;

8. Gavar State University, "Service" specialization;

9. European Educational Regional Academy, "Service" specialization;

10. Armenian Institute of Tourism (the branch of the Russian International Academy of Tourism), "Tourism Management" specialization (Armenian Institute of Tourism);

11. Yerevan branch of the Russian State University of Tourism and Service, "Tourism" specialization 
(Yerevan branch of the Russian State University of Tourism and Service).

With the Masters' degree qualification, Tourism Specialists are preparing in (Decree of the Government of the RA of April 20, 2017, N $435-$ N):

1. YSU and YSU ljevan branch, "Service" specialization;

2. Yerevan State Linguistic University after Bryusov, "Service" specialization;

3. Public Administration Academy of the RA, "Tourism Management" specialization;

4. Armenian State University of Economics, "Tourism Management" specialization;

5. International Scientific-Educational Center of the National Academy of Sciences of the Republic of Armenia, "Tourism management" specialization (International Scientific-Educational Center of the National Academy of Sciences of the RA).

It should be noted that currently there are not state educational criteria for higher educational institutions for the mentioned specialties, but descriptions of specialties are at the stage of development where minimum requirements and end-results should be established. This means that now each university is free to define its one requirements and end-results for their specialties, and as they don't make it public, in order other universities not to take and copy that, it was impossible to analyze it.

In vocational educational institutions, tourism specialists are being prepared in the following fields: Yerevan State Humanitarian College, "Organization of Tourism services with the Advanced Study of Foreign Languages" specialization, which gives the qualification of a manager of tourism services (Yerevan State Humanitarian College); Yerevan-Greece State College of Tourism, Service and Food Industry, "Tourism" and "Service organization in Hotel and Tourism Complexes" specializations, which give qualifications of a tourism service provider specialist and hotel and tourist complex manager.

For the purpose of the analysis, the requirements for the professions prepared by the vocational educational institutions in the field of tourism have been analyzed.

Under the main educational programs of the three above mentioned specialties, a graduate should:

1) Have professional activities in the field of theoretical and practical knowledge required to formulate the necessary capacity for their professional role in this field;

2) ability to communicate with colleagues and managers, to present professional and general questions, to clarify them while performing their professional duties;

3) have the ability to propose professional and alternative solutions to the problems that arise in certain situations;

4) the ability to combine and integrate the facts and information necessary for solving professional problems and demonstrate civic consciousness;

5) have the skills to carry out the functions of professional activity in accordance with the established norms;

6) to demonstrate the ability to evaluate the professional needs of the employee and the staff and to make suggestions on their settlement;

7) have the ability to continually improve professional skills and ability to self-training;

8) the ability to display, access and use the professional and general information;

9) have the skills of organizing the employees' work or coordinating their partnerships (in case of authority);

10) ability to apply elements of strategic approach while demonstrating current professional issues.

The general humanitarian, social-economical and natural sciences subjects that are defined by the curriculum of these three specialties are: Fundamentals of the Armenian Language and Speech Culture (72 hours), Fundamentals of Political Science and Sociology (54 hours), Fundamentals of Economics (54 hours), Principles of Law (36 hours), History (54 hours), Russian Language (72 hours), Foreign Language (72 hours), Physical Education (110 hours), Landscape Studies and Ecology Basics (36 hours), Civil Defense and Emergency Situations Issues (18 hours). Modules of the key learning skills of these 
specialties are: Communication (36 hours), Security and first aid (36 hours); General skills of working activity (54 hours). Now let's look at the peculiarities of each profession.

The specialist in the field of "Organization of Tourism services with the Advanced Study of Foreign Language" (Order of the Minister of Education and Science of the Republic of Armenia N 410-N, 2015) carries out the following activities: service provision manager, organizer, with specialized foreign language skills; head of sales of tourism products, organizer, with specialized foreign language skills; organizer of hotel services with a specialized foreign language ability; head of touristic group, with specialized foreign language skills; guides, accompanying, with specialized foreign language skills; foreign language documentation and communication specialist, in services sphere (translator).

Modules of general professional and special professional capacities of the "Organization of Tourism services with the Advanced Study of Foreign Language" are:

1. Communication in a foreign language - 1 (90 hours);

2. Communication in a foreign language - 2 (90 hours);

3. Geography (72 hours);

4. Computer operator and professional activity (108 hours);

5. Professional communication in a foreign language - 1 ( 150 hours);

6. Professional communication in a foreign language - 2 (150 hours);

7. Professional communication in a foreign language - 3 (150 hours);

8. Organization of service maintenance in a foreign language ( 72 hours);

9. Practical translation of the professional material of the service sector (72 hours);

10. Professional Armenian language in historical-architectural and cultural spheres (68 hours);

11. Professional Armenian language in the field of tourism services (68 hours);

12. Professional Armenian language in hotel services organization ( 54 hours)

13. Professional Armenian language in events and other services organizations (54 hours);

14. Basis for Organization of Services and Legal Regulation (54 hours);

15. Applied economics and business skills (68 hours);

16. Marketing skills ( 54 hours);

17. General Management Skills (72 hours);

18. Business Communication Skills ( 36 hours);

19. Management Skills, Psychology and Service Ethics (36 hours)

20. Conflict, Change and Stress Management (36 hours);

21. Recognition of tourism and tourism services (72 hours);

22. International Tourism Regulation (42 hours);

23. Tourism resources ( 150 hours);

24. Travel organizations and their services (72 hours);

25. Travel Organization (90 hours);

26. Organization of basic services in hotels (72 hours);

27. Catering services (36 hours);

28. Transportation services in tourism (36 hours).

The specialist in "Tourism" profession carries out the following occupations: organizer of tourism production of tourism service and / or package design and development, specialized tourism organizations or their subdivisions; sales organizer of specialized organizations providing tourism services or their subdivisions. Modules of general professional and special professional capacities of the "Tourism" specialty are:

1. Computer Operator Skills (72 hours);

2. Professional communication in a foreign language (90 hours);

3. Applied economics and business skills (90 hours); 
4. Marketing skills (72 hours);

5. General Management Capacity (72 hours);

6. Business Communication Skills (68 hours);

7. Conflict, change and stress management (72 hours);

8. Recognition of tourism and tourism services (90 hours);

9. International tourism regulations (68 hours);

10. Tourism resources (72 hours);

11. Types and classification of hotels, tourist complexes and rooms (72 hours);

12. Catering services (72 hours);

13. Transportation services in tourism (72 hours);

14. Development of tour package (120 hours);

15. Tour package presentation to relevant agents, improvement and sale of tour package (72 hours) (Order of the Minister of Education and Science of the Republic of Armenia N 411-N, 2015).

The specialist in the specialty "Service organization in Hotel and Tourism Complexes" (Order of the Minister of Education and Science of the Republic of Armenia N 1166-N, 2016) carries out the following occupations: manager of the main services' at hotel facilities; supplementary services' manager at hotel facilities; service manager in tourist complexes; manager of business and cultural events, celebrations and ceremonies at hotels and tourist complexes; event tourism manager at hotels and tourist complexes. Modules of general professional and special professional capacities of the "Organization of Service in Hotels and Tourism Complexes" are:

1. Computer Operator ( 72 hours);

2. MS POWERPOINT (36 hours);

3. Data Bank MICROSOFT ACCESS (36 hours);

4. Professional communication in a foreign language -1 (180 hours);

5. Professional communication in a foreign language -2 (180 hours);

6. Professional communication in a foreign language -3 (108 hours);

7. Applied economics and business skills (120 hours);

8. The tourism industry ( 36 hours);

9. Marketing skills (108 hours);

10. General Management skills ( 108 hours);

11. Staff management (108 hours);

12. Management Skills, Psychology and Hospitality Ethics ( 90 hours);

13. Business Communication Skills (72 hours);

14. Conflict, change and stress management in hotels and tourism complexes (72 hours);

15. Accounting skills ( 36 hours);

16. Recognition of national, cultural and religious features ( 36 hours);

17. Recognition of hotels and tourist complexes (140 hours);

18. Organization of basic services in hotel complexes (200 hours);

19. Organization of additional services in hotels and tourist complexes (108 hours);

20. Organization of support services in hotels and tourist complexes (72 hours);

21. Organization and maintenance of events (MICE) in hotels and tourist complexes (180 hours).

Getting acquainted with the main peculiarities of the above mentioned three specialties in the state educational standards, we may say that they all provide subjects essential for basic development as well as the main professional subjects related to practical knowledge of economics, management, marketing and tourism.

It should also be noted that the statistical data about the number of applicants, students and graduates in tourism specialties of vocational and higher educational institutions is not calculated and published 
separately. There is not any information on how many graduates have found professional work as well.

Analysis of students' and graduates' opinions. As mentioned in the method, we have conducted a survey by questionnaire among the students, graduates and employees of tourism sphere to find out their degree of satisfaction with education, their complaints and suggestions. 100 people participated in the survey. The survey was made by focus groups, mainly students/graduates of the following educational institutions: Armenian State University of Economics, Public Administration Academy of the RA, Armenian State Pedagogical University after Kh. Abovyan, Yerevan State University, Yerevan State Linguistic University after V. Bryusov, Armenian National University of Architecture and Construction, European Educational Regional Academy, Armenian-Russian University, Armenian Institute of Tourism, Yerevan State Humanitarian College. $30 \%$ of the participants were graduates, $70 \%$ were students. $47 \%$ of participants noted that they did not work and $53 \%$ were working. $55 \%$ of the participants worked in tourism sphere, $45 \%$ not in tourism sphere. The nature of the work of the workers was mainly guides, inbound tour manager, outbound tour manager, sales manager, financial manager, marketing manager, administrator at the hotel, consultant, airline sales specialist, etc. Most of the participants (47\%) assessed their education as mainly theoretical with some practical work, $27 \%$ mentioned being mostly theoretical, $19 \%$ mentioned that theoretical and practical parts were equal, and $7 \%$ mentioned mostly practical. The participants assessed their satisfaction with education as follows (Table 1).

Table 1 - Satisfaction with education

\begin{tabular}{|c|c|c|c|c|c|}
\hline & & Frequency & Percent & Valid Percent & $\begin{array}{c}\text { Cumulative } \\
\text { Percent }\end{array}$ \\
\hline \multirow[t]{6}{*}{ Valid } & not satisfied & 2 & 2.0 & 2.0 & 2.0 \\
\hline & not satisfied at all & 20 & 20.0 & 20.0 & 22.0 \\
\hline & satisfied & 25 & 25.0 & 25.0 & 47.0 \\
\hline & somehow satisfied & 40 & 40.0 & 40.0 & 87.0 \\
\hline & very satisfied & 13 & 13.0 & 13.0 & \\
\hline & Total & 100 & 100.0 & 100.0 & \\
\hline
\end{tabular}

The respondents evaluated the main factors that impact on their satisfaction with the education: Theoretical knowledge; Practical knowledge and skills; Be competitive in the labor market based on the knowledge gained; The possibility of rapid self-establishment in the labor market based on the education received; The opportunity to find a highly rewarded job in the labor market based on the knowledge gained; Finding an international job.

The cross-tabulation and testings between satisfaction and the main factors show, that satisfied and very satisfied people mainly indicated practical knowledge and skills, somehow satisfied people mentioned practical knowledge and skills, being competitive in the labor market and the opportunity to find a highly rewarded job (Table 2, 3, 4).

Table 2 - Chi-Square testing

\begin{tabular}{|l|r|r|r|}
\hline & Value & df & \multicolumn{1}{c|}{$\begin{array}{c}\text { Asymp. Sig. } \\
\text { (2-sided) }\end{array}$} \\
\hline Pearson Chi-Square & $17.341^{\mathrm{a}}$ & 20 & .631 \\
Likelihood Ratio & 20.892 & 20 & .404 \\
N of Valid Cases & 100 & & \\
\hline
\end{tabular}

a. 24 cells $(80.0 \%$ ) have expected count less than 5 . The minimum expected count is .14 . 
G. Tovmasyan. New and Innovative Solutions for Improving Tourism Education and Raising Satisfaction of Students in Armenia

Table 3 - Phi, Cramer's V and Contingency Coefficient testing

\begin{tabular}{|ll|c|r|}
\hline & & Value & Approx. Sig. \\
\hline Nominal by Nominal & Phi & .416 & .631 \\
& Cramer's V & .208 & .631 \\
& Contingency Coefficient & .384 & .631 \\
N of Valid Cases & & 100 & \\
\hline
\end{tabular}

Table 4 - Cross-tabulation between the factors and satisfaction with the education

\begin{tabular}{|c|c|c|c|c|c|c|c|c|c|}
\hline & & & \multicolumn{6}{|c|}{ Factors } & \multirow[b]{2}{*}{ Total } \\
\hline & & & $\begin{array}{c}\mathrm{Be} \\
\text { competitive in } \\
\text { the }\end{array}$ & $\begin{array}{c}\text { Finding an } \\
\text { internatio }\end{array}$ & $\begin{array}{c}\text { Practical } \\
\text { knowledge a }\end{array}$ & $\begin{array}{c}\text { The } \\
\text { opportunity to } \\
\text { fi }\end{array}$ & $\begin{array}{c}\text { The } \\
\text { possibility of } \\
\text { ra }\end{array}$ & $\begin{array}{l}\text { Theoretical } \\
\text { knowledge }\end{array}$ & \\
\hline \multirow[t]{25}{*}{ Satisfaction } & \multirow[t]{5}{*}{ not satisfied } & Count & 0 & 0 & 1 & 1 & 0 & 0 & 2 \\
\hline & & Expected Count & .4 & .1 & .7 & .3 & .2 & .3 & 2.0 \\
\hline & & $\%$ within Satisfaction & $0.0 \%$ & $0.0 \%$ & $50.0 \%$ & $50.0 \%$ & $0.0 \%$ & $0.0 \%$ & $100.0 \%$ \\
\hline & & $\%$ within Factors & $0.0 \%$ & $0.0 \%$ & $2.8 \%$ & $5.9 \%$ & $0.0 \%$ & $0.0 \%$ & $2.0 \%$ \\
\hline & & $\%$ of Total & $0.0 \%$ & $0.0 \%$ & $1.0 \%$ & $1.0 \%$ & $0.0 \%$ & $0.0 \%$ & $2.0 \%$ \\
\hline & \multirow[t]{5}{*}{ not satisfied at all } & Count & 3 & 0 & 6 & 5 & 3 & 3 & 20 \\
\hline & & Expected Count & 3.6 & 1.4 & 7.2 & 3.4 & 1.8 & 2.6 & 20.0 \\
\hline & & $\%$ within Satisfaction & $15.0 \%$ & $0.0 \%$ & $30.0 \%$ & $25.0 \%$ & $15.0 \%$ & $15.0 \%$ & $100.0 \%$ \\
\hline & & $\%$ within Factors & $16.7 \%$ & $0.0 \%$ & $16.7 \%$ & $29.4 \%$ & $33.3 \%$ & $23.1 \%$ & $20.0 \%$ \\
\hline & & $\%$ of Total & $3.0 \%$ & $0.0 \%$ & $6.0 \%$ & $5.0 \%$ & $3.0 \%$ & $3.0 \%$ & $20.0 \%$ \\
\hline & \multirow[t]{5}{*}{ satisfied } & Count & 5 & 3 & 10 & 2 & 1 & 4 & 25 \\
\hline & & Expected Count & 4.5 & 1.8 & 9.0 & 4.3 & 2.3 & 3.3 & 25.0 \\
\hline & & $\%$ within Satisfaction & $20.0 \%$ & $12.0 \%$ & $40.0 \%$ & $8.0 \%$ & $4.0 \%$ & $16.0 \%$ & $100.0 \%$ \\
\hline & & $\%$ within Factors & $27.8 \%$ & $42.9 \%$ & $27.8 \%$ & $11.8 \%$ & $11.1 \%$ & $30.8 \%$ & $25.0 \%$ \\
\hline & & $\%$ of Total & $5.0 \%$ & $3.0 \%$ & $10.0 \%$ & $2.0 \%$ & $1.0 \%$ & $4.0 \%$ & $25.0 \%$ \\
\hline & \multirow[t]{5}{*}{ somehow satisfied } & Count & 9 & 3 & 13 & 9 & 2 & 4 & 40 \\
\hline & & Expected Count & 7.2 & 2.8 & 14.4 & 6.8 & 3.6 & 5.2 & 40.0 \\
\hline & & $\%$ within Satisfaction & $22.5 \%$ & $7.5 \%$ & $32.5 \%$ & $22.5 \%$ & $5.0 \%$ & $10.0 \%$ & $100.0 \%$ \\
\hline & & $\%$ within Factors & $50.0 \%$ & $42.9 \%$ & $36.1 \%$ & $52.9 \%$ & $22.2 \%$ & $30.8 \%$ & $40.0 \%$ \\
\hline & & $\%$ of Total & $9.0 \%$ & $3.0 \%$ & $13.0 \%$ & $9.0 \%$ & $2.0 \%$ & $4.0 \%$ & $40.0 \%$ \\
\hline & \multirow[t]{5}{*}{ very satisfied } & Count & 1 & 1 & 6 & 0 & 3 & 2 & 13 \\
\hline & & Expected Count & 2.3 & .9 & 4.7 & 2.2 & 1.2 & 1.7 & 13.0 \\
\hline & & $\%$ within Satisfaction & $7.7 \%$ & $7.7 \%$ & $46.2 \%$ & $0.0 \%$ & $23.1 \%$ & $15.4 \%$ & $100.0 \%$ \\
\hline & & $\%$ within Factors & $5.6 \%$ & $14.3 \%$ & $16.7 \%$ & $0.0 \%$ & $33.3 \%$ & $15.4 \%$ & $13.0 \%$ \\
\hline & & $\%$ of Total & $1.0 \%$ & $1.0 \%$ & $6.0 \%$ & $0.0 \%$ & $3.0 \%$ & $2.0 \%$ & $13.0 \%$ \\
\hline \multirow{5}{*}{\multicolumn{2}{|c|}{ Total }} & Count & 18 & 7 & 36 & 17 & 9 & 13 & 100 \\
\hline & & Expected Count & 18.0 & 7.0 & 36.0 & 17.0 & 9.0 & 13.0 & 100.0 \\
\hline & & $\%$ within Satisfaction & $18.0 \%$ & $7.0 \%$ & $36.0 \%$ & $17.0 \%$ & $9.0 \%$ & $13.0 \%$ & $100.0 \%$ \\
\hline & & $\%$ within Factors & $100.0 \%$ & $100.0 \%$ & $100.0 \%$ & $100.0 \%$ & $100.0 \%$ & $100.0 \%$ & $100.0 \%$ \\
\hline & & $\%$ of Total & $18.0 \%$ & $7.0 \%$ & $36.0 \%$ & $17.0 \%$ & $9.0 \%$ & $13.0 \%$ & $100.0 \%$ \\
\hline
\end{tabular}

Thus, the testing analyses show that the value of significance is 0.631 , which means that there is a significant association between and satisfaction and several factors.

The participants assessed the following subjects according to their significance level to become a tourism specialist in the following way (Table 5).

Table 5 - Subjects that are important to become a good specialist

\begin{tabular}{|l|c|c|c|c|c|}
\hline \multicolumn{1}{|c|}{ Subjects } & $\begin{array}{c}\text { not important } \\
\text { at all }\end{array}$ & not important & $\begin{array}{c}\text { of medium } \\
\text { importance }\end{array}$ & important & $\begin{array}{c}\text { very } \\
\text { important }\end{array}$ \\
\hline \multicolumn{1}{|c|}{$\mathbf{1}$} & $\mathbf{2}$ & $\mathbf{3}$ & $\mathbf{4}$ & $\mathbf{5}$ & $\mathbf{6}$ \\
\hline History of tourism & 2 & 12 & 28 & 26 & 15 \\
\hline Tourism Industry & 3 & 5 & 21 & 28 & 21 \\
\hline Tourism Management & 2 & 1 & 6 & 28 & 48 \\
\hline Tourism Strategic Management & 2 & 2 & 10 & 30 & 36 \\
\hline Tourism Marketing & 1 & - & 4 & 33 & 49 \\
\hline Tour-operating & 2 & - & 8 & 35 & 40 \\
\hline
\end{tabular}


Table 5

\begin{tabular}{|l|c|c|c|c|c|}
\hline \multicolumn{1}{|c|}{$\mathbf{1}$} & $\mathbf{2}$ & $\mathbf{3}$ & $\mathbf{4}$ & $\mathbf{5}$ & $\mathbf{6}$ \\
\hline Electronic Tourism & 2 & - & 13 & 33 & 34 \\
\hline Management of Tourism Resources & 2 & - & 7 & 33 & 39 \\
\hline Sustainable Tourism & 2 & 2 & 9 & 29 & 39 \\
\hline $\begin{array}{l}\text { Management of Human Resources in } \\
\text { Tourism }\end{array}$ & 2 & 2 & 14 & 29 & 36 \\
\hline Tourism Economics & 3 & 4 & 15 & 30 & 30 \\
\hline Tourism Geography & 2 & - & 14 & 35 & 34 \\
\hline Tourism Policy and Legal Regulation & 3 & 4 & 15 & 34 & 22 \\
\hline Tourist Psychology and Behavior Analysis & 2 & 3 & 11 & 33 & 36 \\
\hline Business Communication in Tourism & 2 & 2 & 10 & 34 & 34 \\
\hline Management of Tourism Destinations & 2 & 4 & 14 & 26 & 32 \\
\hline Development of Tourism Infrastructures & 2 & 1 & 8 & 28 & 42 \\
\hline Management of Investments in Tourism & 2 & - & 9 & 31 & 38 \\
\hline Development of Tourism Product & 1 & 1 & 6 & 32 & 44 \\
\hline Business tourism organization & 2 & 1 & 10 & 28 & 33 \\
\hline Management of Hospitality Industry & 2 & 1 & 10 & 33 & 37 \\
\hline Organization of Food Services & 2 & 1 & 18 & 28 & 36 \\
\hline Management of Transport Infrastructures & 2 & 1 & 18 & 27 & 35 \\
\hline Event Management & 2 & 1 & 17 & 32 & 32 \\
\hline Tourism Industry Research Methodology & 3 & 7 & 17 & 32 & 18 \\
\hline Tourism, Culture and Society & 2 & 3 & 14 & 33 & 33 \\
\hline Tourism planning and development & 2 & 1 & 9 & 35 & 37 \\
\hline Tourism Statistics & 2 & 6 & 17 & 34 & 19 \\
\hline Scientific Tourism & 2 & 4 & 23 & 37 & 13 \\
\hline $\begin{array}{l}\text { International regulations of tourism } \\
\text { industry }\end{array}$ & 2 & 4 & 21 & 28 & 28 \\
\hline
\end{tabular}

From the main subjects the participants have studied the following:

1. History of tourism $-55 \%$ of the participants;

2. Tourism Industry $-40 \%$ of the participants;

3. Tourism Management $-57 \%$ of the participants;

4. Tourism Strategic Management $-27 \%$ of the participants;

5. Tourism Marketing $-52 \%$ of the participants;

6. Tour-operating $-55 \%$ of the participants;

7. Electronic Tourism $-9 \%$ of the participants;

8. Management of Tourism Resources $-47 \%$ of the participants;

9. Sustainable Tourism $-37 \%$ of the participants;

10. Management of Human Resources in Tourism - 30\% of the participants;

11. Tourism Economics - $44 \%$ of the participants;

12. Tourism Geography - $59 \%$ of the participants;

13. Tourism Policy and Legal Regulation $-27 \%$ of the participants;

14. Tourist Psychology and Behavior Analysis - $33 \%$ of the participants;

15. Business Communication in Tourism - $34 \%$ of the participants;

16. Management of Tourism Destinations $-23 \%$ of the participants;

17. Development of Tourism Infrastructures $-29 \%$ of the participants;

18. Management of Investments in Tourism - 13\% of the participants;

19. Development of Tourism Product $-34 \%$ of the participants;

20 . Business tourism organization $-20 \%$ of the participants;

21. Management of Hospitality Industry $-48 \%$ of the participants; 
22. Organization of Food Services - $48 \%$ of the participants;

23. Management of Transport Infrastructures - $43 \%$ of the participants;

24. Event Management $-30 \%$ of the participants;

25. Tourism Industry Research Methodology $-17 \%$ of the participants;

26. Tourism, Culture and Society $-39 \%$ of the participants;

27. Tourism planning and development $-26 \%$ of the participants;

28. Tourism Statistics $-22 \%$ of the participants;

29. Scientific Tourism $-15 \%$ of the participants;

30. International regulations of tourism industry $-19 \%$ of the participants.

Besides, the following subjects were also mentioned: Homeland Studies and Tourism, Guides, Event Tourism, Sport and Health Tourism, World Cultural Heritage and Tourism Resources, Armenian Architecture, Theory of Tourism Organizations, Sociology of Tourism, Hospitality Management, Cartography. The participants also mentioned the most important skills that they have received during educational process:

- Communication skills - $69 \%$ of the participants;

- Negotiation skills - $39 \%$ of the participants;

- Management skills $-47 \%$ of the participants;

- Leadership skills - $30 \%$ of the participants;

- Time management skills $-27 \%$ of the participants;

- Team-working skills $-59 \%$ of the participants;

- Initiatives $-36 \%$ of the participants;

- Creativity $-44 \%$ of the participants;

- Strategic mindset $-27 \%$ of the participants;

- Analytical skills - $50 \%$ of the participants;

- Decision making skills $-47 \%$ of the participants;

- Flexible thinking and behavior $-46 \%$ of the participants;

- Organizational skills $-50 \%$ of the participants;

- Purposefulness - $36 \%$ of the participants;

- Stress resistance $-36 \%$ of the participants;

- Sense of responsibility - $42 \%$ of the participants;

- Working ethics $-60 \%$ of the participants;

- Research skills $-33 \%$ of the participants;

- Knowledge of foreign languages $-73 \%$ of the participants;

- Professional knowledge $-78 \%$ of the participants;

- Computer skills (including touristic computer programs, AMADEUS, GABRIEL, etc.) $-24 \%$ of the participants;

Participants from the Armenian Tourism Institute also mentioned that practical trainings were organized for them in travel agencies, hotels of different classes, and in other organizations of service sector.

Participants mentioned the following complaints about organization of education:

1. Excessive theoretical training, lack of practical subjects which knowledge can be used in practice in future;

2. Lack of practical training, practical knowledge and skills gained in practice, the education is mostly theoretical, and the practice is minimal due to very badly organized practices;

3. There are few professional subjects;

4. There is almost no literature in Armenian; 
5. There are many gaps in the formulation of a specialist for the labor market;

6. Short time of experience, irresponsible attitude to the student, no assistance or suggestions;

7. Practice is not enough, the materials are very old, the lecturers are not developed, the lessons are not interesting, students want professional fresh and deep knowledge, as the lecturers do not follow the news, do not talk on these topics, the exams are very stressful;

8. It would be good if the subjects were really related to tourism;

9. Not high level of foreign language learning;

10. The main problem is the absence of the link between labor market and education;

11. The same specialist always teaches several subjects in the same way;

12. Lack of tourist software, the aforementioned computer programs are not taught at the university, whereas with the 4-year tuition fee $(2,400,000 \mathrm{AMD})$ could be provided and taught even only the Amadeus program.

The participants mentioned the following suggestions to improve the organization of tourism education:

1. Start studying tourism subjects from elementary school;

2. Use the full potential of Armenia's tourism, focus on the powerful potential of regions, which is almost not used;

3. To make education more practical, to organize internships not only for the study of natural and historical-architectural objects, but also for the purpose of gaining work experience in travel agencies;

4. Full implementation of the above-mentioned skills;

5. Focus more on professional subjects and allow the acquired knowledge to be used more in the business environment;

6. Besides paying attention to the theoretical part, also the acquisition of professional skills and experience;

7. Teaching through interactive methods, paying more attention to practical training, increasing practical work;

8. Organize free excursions, in order to know Armenia better during the years of learning;

9. Tourist software programs at the University, highlight the development of computer skills; Include at least one Amadeus, Gabriel or similar program;

10. Specialized, in-depth training of foreign languages;

11. Instead of day-to-day practices, it is desirable that every future specialist should feel himself as a specialist or worker in tourism industry for 2-3 days;

12. To organize the practice through short-term activities so that the student can better understand the theory, have experience;

13. Review the gaps in education, add relevant lessons, combine theory with practice, include more specialized subjects;

14. Let internships become a means of getting acquainted with the nature of work in a traveling organization and finding a job in the future;

15. Give great importance to geography, strategic planning and tourism statistics;

16. Involve specialists who have success and practice in tourism in the field of education;

17. It would be good to divide the learning process into $30 \%$ theoretical and $70 \%$ practical parts, as the theoretical part is often transformed into memorizing and later forgotten;

18. It would be desirable to pay close attention to tourism development issues in Armenia;

19. To strengthen the cooperation with the private sector, to invite the best guides as a guest speaker, who can share their experiences and offer practical solutions for different situations, introduce the students to the touristic activity of the main service providers but not only in theoretical and specific visits. Implementation of personnel distribution throughout the Republic so that tourism can develop on a nation- 

in Armenia

wide basis, not focus on several places. It is important that guides know foreign languages, teach them how to deal with a foreigner, develop ethics in every field.

20. Obtain practical knowledge appropriate to the employer's requirements and to replenish libraries with new literature;

21. Practical experience abroad.

Thus, based on above mentioned analysis, we may resume the main results in SWOT matrix (Table 6).

Table 6- SWOT analysis of tourism education and labor market issues

\begin{tabular}{|c|c|c|c|}
\hline Strengths & Weaknesses & Opportunities & Threats \\
\hline $\begin{array}{l}\text { Tourism specialties in } \\
\text { higher and vocational } \\
\text { educational institutions }\end{array}$ & $\begin{array}{l}\text { The absence of state } \\
\text { educational requirements for } \\
\text { tourism specialties for higher } \\
\text { educational institutions }\end{array}$ & $\begin{array}{l}\text { Increasing the level of } \\
\text { more practical studies }\end{array}$ & $\begin{array}{l}\text { Low income level } \\
\text { of population }\end{array}$ \\
\hline \multirow{2}{*}{$\begin{array}{l}\text { The existence of big } \\
\text { tourism industry in } \\
\text { Armenia }\end{array}$} & $\begin{array}{l}\text { The absence of statistics of the } \\
\text { number of students, graduates } \\
\text { and employers in tourism }\end{array}$ & $\begin{array}{l}\text { Applying more interactive } \\
\text { methods of learning }\end{array}$ & \multirow{2}{*}{$\begin{array}{l}\text { Migration of } \\
\text { population }\end{array}$} \\
\hline & $\begin{array}{l}\text { Mostly theoretical studies in } \\
\text { Institutions and lack of practice }\end{array}$ & $\begin{array}{l}\text { Including specialists from } \\
\text { labor market in education } \\
\text { process }\end{array}$ & \\
\hline
\end{tabular}

Conclusion. The conducted research lets us draw some conclusions.

- Studies in Universities and colleges are mostly theoretical, with little practical work;

- The specialists of the sphere are not properly included in educational process;

- As we have seen in the educational programs and survey results of students, there are no subjects of AMADEUS, GABRIEL, and many people learn them in private courses (as for higher educational institutions, these subjects are studied only in few places);

- The number of applicants, students and graduates in the respective specialties of vocational and higher educational institutions is not calculated and published separately. There is not also any information on how many graduates have found professional work;

- Studies in universities and colleges are mostly theoretical, students are dissatisfied with the lack of practical training, advanced training of professional subjects, organization of internships, professionalism of teaching specialists, lack of professional literature in Armenian;

- The cross-tabulation and other testing analyses showed that the main factors that influence on the satisfaction of students with their education were: practical knowledge and skills, being competitive in the labor market and the opportunity to find a highly rewarded job.

Thus, we may make some suggestions for improving the organization of educational process. At first the educational programs and subjects should arise from the needs of labor market. The proficient specialists from the sphere are likely to be included in educational process as trainers and lecturers. Besides, the education must be more practical, interactive methods should be used in order to strengthen the theoretical knowledge via practical work, and the practice of students must be organized in proper way in tourism organizations. Tourism subjects should be included also in elementary school programs. The statistics of the sphere also should be improved, in order to have data about the number of students and graduates of tourism specialties, which will allow increasing the effectiveness of research in the field.

Admission places for Master's degree for 2017/2018 academic year, with full-time, state-funded tuition fees, Decree of the Government of the RA of April 20, 2017, N 435 - N

Admission places for Bachelor's degree for 2017/2018 academic year, with full-time, state-funded tuition fees and a partial deduction of tuition fees (paid) by the state, Appendix N 1 of the Decision of the Government of the Republic of Armenia No 434-N 
of April 20, 2017

Annaraud, K., \& Singh, D. (2017). Perceptions of hospitality faculty and students of massive open online courses (MOOCs). Journal of Hospitality and Tourism Education, 29(2), 82-90.

Armenian Institute of Tourism, http://www.ait.am/?id=51\&lng=5

Atay, L. and Yildirim, H.M. (2010) Determining Factors that Affect Satisfaction of Students in Undergraduate Tourism Education.

Tourismos: An International Multidisciplinary Journal of Tourism. Vol. 5, No. 1, pp. 73-87.

Bogolyubov, V.S. (2005) Economics of tourism, Academia publishing, p. 6 (in Russian)

Butler, R. W. (1999) Understanding Tourism. In E. L. Jackson and Burton, T. L. (Eds.), Leisure Studies: prospects or the twentyfirst century, (pp. 97-116). State College, PA: Venture.

Green, A. J., \& Sammons, G. E. (2014). Student learning styles: Assessing active learning in the hospitality learners' model. Journal of Hospitality and Tourism Education, 26(1), 29-38.

International Scientific-Educational Center of the National Academy of Sciences of the Republic of Armenia, http://isec.am/admissions/master/entrant.html

Jurowski, C. (2002) BEST Think Tank and the Development of Curriculum Modules for Teaching Sustainability Principles. Journal of Sustainable Tourism, Vol. 10(6), pp. 536-545.

Morgan, M. (2004) From Production Line to Drama School: Higher Education for the Future of tourism. International Journal of Contemporary Hospitality Management, Vol. 16(2), pp. 91-99.

Order of the Minister of Education and Science of the Republic of Armenia N 410-N, 08.05.2015, for the approval of the state educational standard of 2-74.30.02 "Organization of Tourism services with the Advanced Study of Foreign Languages" specialty, with the qualification 74.30.02.01-4 "Tourism Services Manager", pp. 1-101

Order of the Minister of Education and Science of the Republic of Armenia N 411-N, 08.05.2015, for the approval of the state educational standard of 1015.01.5 "Tourism" specialty, with the qualification 1015.01.01.5 "Tourism service provider specialist ", pp. $1-59$

Order of the Minister of Education and Science of the Republic of Armenia N 1166-N, 14.11.2016, for the approval of the state educational standard of 0413.05.5 "Service organization in Hotel and Tourism Complexes" specialty, with the qualification 0413.05.01.5 "Hotel and tourist complex manager"

Patiar, A., Ma, E., Kensbock, S., \& Cox, R. (2017). Hospitality management student' expectation and perception of a virtual field trip web site: An Australian case study using importance-performance analysis. Journal of Hospitality and Tourism Education, 29(1) $1-12$.

Riley, M., Ladkin, A., \& Szivas, E. (2002). Tourism Employment: Analysis and Planning. UK:Channel View Publications.

Sander, P., Stevenson, K., King, M., \& Coates, D. (2000). University students' expectations of teaching. Studies in Higher Education, 25(3), 309-323. doi:10.1080/03075070050193433

Social-economic situation in the RA in 2017 January-December, p. 132, http://armstat.am/file/article/sv_12_17a_421.pdf

Sola, E. F. (2002). Tourism employment: towards a new paradigm. In: World Tourism Organization. Human Resources in Tourism: Towards a new paradigm, (pp. 223-226).

Madrid: OMT.

Stevenson, K., \& Sander, P. (1998). How do Open University students, expect to be taught at tutorials? Open Learning: The Journal of Open and Distance Learning, 13(2), 42-46. doi:10.1080/ 0268051980130208

The Travel \&Tourism Competitiveness Report (2017) World Economic Forum, Geneva, p. 85

Travel \& Tourism Economic Impact, World (2017) p. 1, https://www.wttc.org///media/files/reports/economic-impactresearch/regions-2017/world2017.pdf

Travel \& Tourism Economic Impact, Armenia (2017), p. 1

Yerevan branch of the Russian State University of Tourism and Service, http://rgutis.am/priem-2017

Yerevan State Humanitarian College, http://ephq.am/\%D5\%A4\%D5\%AB\%D5\%B4\%D5\%B8\%D6\%80\%D5\%A4/

Yiu, M., \& Law, R. (2012). A review of hospitality internship: Different perspectives of students, employers, and educators. Journal of Teaching in Travel and Tourism, 12(4), 377-402.

Г. Товмасян, Ph.D., профресор, дослідницький центр " AMBERD", Вірменський державний економічний університет, Академія державного управління Республіки Вірменія (Єреван, Вірменія).

Інноваційні рішення для удосконалення системи освіти в галузі туризму та підвищення рівня задоволеності студентів освітнім процесом у Вірменії

Основною метою дослідження є виявлення прогалин та проблем освіти в галузі туризму, оцінювання рівня задоволеності студентів Вірменії результатами та технологіями освітнього процесу. Методичними інструментами дослідження стали статистичні методи та SWOT-аналіз. Дослідження побудовано за наступною структурно-логічною схемою: в першій частині досліджено механізми організації навчального процесу та здійснено аналіз освітніх програм ө галузі туризму у закладах вищої та професійно-технічної освіти Вірменії, в другій частині продемонстровано результати опитування серед студентів, випускників та працівників сфери туризму щодо їх очікувань та сприйняття навчання, в третій частині систематизовано скарги та пропозиціі студентів, які можуть бути врахованів майбутньому 


\begin{abstract}
3 метою покращення навчального процесу. Вибірка респондентів склала 100 осіб, з яких 30\% - випускники, 70\% студенти. 47\% учасників зазначили, що вони не працюють в поточний момент, а 53\% респондентів працюють. $55 \%$ учасників мають досвід працевлаштування у ссрері туризму, 45\% - не в туристичній сфрері. Більшість учасників (47\%) оцінили отримані під час освіти знання як переважно теоретичні з незначним практичним спрямуванням, 27\% - як суто теоретичні, 19\% зазначили, що теоретичні та практичні частини є однаковими, та лише $7 \%$ респондентів вважають отримані знання та навички такими, які адаптовані до практики. Для оцінювання рівня задоволеності результатами освітнього процесу в статті запропоновано систему критеріїв, які визначають суб'єктивне сприйняття респондентами достатності отриманих теоретичних знань та практичних навичок для того, щоб бути конкурентоспроможним на національному та міжнародному ринку праці, швидко знайти роботу, претендувати на високий рівень оплати праці тощо. За допомогою методу крос-табуляції визначено рівень задоволеності результатами освітнього процесу за кожним фактором, що його визначає. Розрахунок критерію Пірсона дозволив підтвердити статистичну значущість отриманих результатів. Наступним етапом дослідження стало опитування респондентів щодо рівня значущості конкретних навчальних дисциплін для професійного самовизначення в галузі туризму. Результати проведеного аналізу ссормуввали підгрунтя для коригування структури навчальних планів під реальнівимоги ринку праці туристичної галузі. Проведене опитування засвідчило, що туристична освіта в Вірменії має чимало інших проблем: наукові розробки в цій галузі переважно теоретичні, незначна кількість тренінгів та індивідуальних занять, неефективна організація практичної підготовки та стажувань, обмаль викладачів-практиків, відсутність можливості опанувати сучасні специярічні програмні продукти, які використовуються в туристичній індустрії тощо. Дослідження емпірично підтверджує і теоретично доводить, що нові методики викладання в галузі туризму є обов'язковими вимогами сучасності для задоволення потреб ринку праці, а студенти є первинними споживачами освітніх послуг, які все більше усвідомлюють свої права як споживачів і висувають все більші вимоги до якості освіти. Дослідження показало, що студенти високо цінують та надають перевагу інтерактивним методам навчання. Результати дослідження можуть бути корисними для навчальних закладів (в контексті вдосконалення освітніх програм), для представників туристичного бізнесу (задля розвитку співпраці з навчальними закладами при підготовці фахівців) та для студентів.

Ключові слова: туризм, освіта, спеціальність, навички, задоволеність, Вірменія.
\end{abstract}

